УДК 621.452.33.017:004.032.26:519.216.3

Ю. М. ШМЕЛЬОВ, С. І. ВЛАДОВ, Я. Р. КЛІМОВА

Кременчуцький льотний коледж Національного авіаційного університету, Украйна

\title{
ЗАСТОСУВАННЯ НЕЙРОННИХ МЕРЕЖ У ЗАДАЧІ ПРОГНОЗУВАННЯ ТЕХНІЧНОГО СТАНУ АВІАЦІЙНОГО ДВИГУНА ТВЗ-117 У ПОЛЬОТНИХ РЕЖИМАХ
}

\begin{abstract}
Предметом вивчення в статті є методи і моделі ідентифікації технічного стану авіаційного двигуна TB3-117. Метою є розробка бортової системи ідентифікації технічного стану авіаційного двигуна ТВ3-117, одним з вирішуваних завдань якої є прогнозування його технічного стану в режимі реального часу. Завдання: розробка методів і алгоритмів прогнозування технічного стану авіаційного двигуна ТВ3-117 в польотних режимах на базі нейромережевої технологї. Використовуваними методами є: методи теорії ймовірностей і математичної статистики, методи нейроінформатики, методи теорії інформаційних систем та обробки даних. Отримані такі результати. Використання запропонованого у роботі нейромережевого методу прогнозування, щзо базується на апроксимації та екстраполяції процесів зміни газодинамічних параметрів авіаційного двигуна ТВ3-117 на фіксованих відрізках часового вікна (в межах «змінного часового вікна»), дозволяє ефективно розв'язати задачу прогнозування його технічного стану. Аналіз ефективності застосування нейромережевого методу прогнозування технічного стану авіачійного двигуна ТВ3-117 в умовах дії випадкових перешкод показує його переваги у порівнянні з класичними методами прогнозування, щчо складаються у забезпеченні більш високої точності прогнозування для різних інтервалів прогнозування (короткострокове, середньострокове, довгострокове прогнозування). Використання розробленого нейромережевого методу дозволяє виявити моменти розв'язання часового ряду, тобто з'ясування тренду параметрів авіаційного двигуна ТВ3-117, щзо є наслідком якості зміни характеристик двигуна, щзо дозволяє своєчасно приймати оперативні рішення щзодо зміни режиму його експлуатації. Висновки. Наукова новизна отриманих результатів полягає в наступному: дістав подальший розвиток метод розв'язку задач прогнозування технічного стану авіачійного двигуна ТВ3-117 за допомогою нейромережевих технологій, точність якого при короткостроковому середньостроковому та довгостроковому прогнозуванні значно вища порівняно з використанням поліноміальних регресійних моделей, методом експоненціального згладжування, змінної середньої, щзо свідчить про те, щзо використання нейромережевих технологій дозволяє виявити появлення тренду параметрів авіаційного двигуна ТВ3-117, щзо дозволяє вживати своєчасні оперативні рішення щзодо зміни режиму його експлуатації.
\end{abstract}

Ключові слова: авіаціийний двигун, нейронна мережа, прогнозування, часовий ряд, помилка.

\section{Вступ}

Безпека польотів повітряного судна - одна 3 ключових проблем авіації, багато в чому залежить від надійності роботи їх двигунів. У наш час технічна діагностика авіаційних двигунів здійснюється тільки на землі інженерно-технічним персоналом, в розпорядженні якого є відповідні інструментальні засоби і методичний апарат. У свою чергу, надійна робота двигуна забезпечується цілим комплексом заходів, серед яких важливе місце відводиться ідентифікації його технічного стану. Оскільки більшість відмов, які впливають на безпеку експлуатації повітряного судна, зароджуються і проявляються саме в польоті, що вимагає наявності ефективної бортової системи ідентифікації технічного стану двигуна у режимі реального часу безпосередньо на борту пові- тряного судна. Труднощі проведення діагностики авіаційного двигуна в автоматичному режимі у польоті пов'язані 3 високою складністю конструкцій авіаційних двигунів, в тому числі, і турбовального двигуна ТВ3-117, обумовленої багатопараметричністю, багатопов'язаністю, нелінійністю процесів, що протікають в них, багаторежимністю застосування, що вимагає значних машинних і часових ресурсів.

На сьогоднішній день двигуни п'ятого покоління мають бортові системи контролю параметрів, які здійснюють видачу інформації про відмови систем і агрегатів, а також про перевищення або зниження допустимих значень деяких параметрів. Ця інформація надходить до екіпажу за допомогою показань бортових приладів, світлових індикаторів або звукових сигналів. У результаті існуючі системи контролю параметрів авіаційних двигунів констатують вже факт відмови, що стався, не даючи мож-

(С Ю. М. Шмельов, С. І. Владов, Я. Р. Клімова 
ливості екіпажу йому запобігти. У сучасних умовах такі системи $\epsilon$ недостатньо ефективними як мінімум 3 двох причин. По-перше, намітилася стійка тенденція переходу від стратегії експлуатації авіаційної техніки «по ресурсу» до експлуатації «за станом» вимагає підвищеної уваги до технічного стану авіаційного двигуна. По-друге, постійне підвищення питомих параметрів, розроблених нових двигунів відбувається за рахунок зниження запасів міцності, стійкості і призводить до їх роботи на граничних режимах, що об'єктивно підвищує ризики виникнення відмов. Таким чином, існує проблема створення нових «інтелектуальних» бортових систем технічної діагностики авіаційних двигунів, здатних ефективно розпізнавати відмови, що зароджуються і здійснювати прогнозування технічного стану авіаційного двигуна хоча б на час, достатній для безпечного завершення польоту [1-3].

Метою даної роботи є розробка бортової системи технічної діагностики авіаційного двигуна ТВ3-117, однією із розв'язуваних задач якої є прогнозування технічного стану авіаційного двигуна у режимі реального часу.

\section{Аналіз останніх досліджень і публікацій}

У даний час проблематикою інформаційної діагностики авіаційної техніки активно займаються вчені Московського державного технічного університету цивільної авіації (МДТУ ЦА), серед яких варто виділити роботи професора О. Ф. Машошина [4-6], в яких застосовані різні методики визначення несправностей авіаційної техніки, в тому числі, і авіаційних двигунів. Велика увага приділялася методам діагностики авіаційної техніки з позиції інформативності та інформаційного забезпечення процесів іiі діагностування.

Також варто відзначити роботи професора C. В. Жернакова (Уфимський державний авіаційний технічний університет) [7-9], присвячені контролю і діагностиці технічного стану авіаційних газотурбінних двигунів на основі інтелектуального аналізу даних.

Але усі праці в даній області присвячені газотурбінним двигунам, які установлені на літаках, наприклад [10]. У силу відмінностей конструктивних особливостей авіаційних вертолітних та літакових двигунів, розробка бортової системи технічної діагностики авіаційного двигуна ТВ3-117 на базі існуючих літакових, $є$ актуальною науково-практичною задачею, у рамках якої у даній науковій статті вирішується питання прогнозування технічного стану авіаційного двигуна ТВ3-117 у режимі реального часу.

\section{Постановка задачі}

При використанні нейронних мереж для вирішення задач ідентифікації технічного стану двигуна наявна апріорна інформація [11] пред'являсться нейронній мережі у вигляді готових рішень (задачників), на основі яких здійснюється процес ії навчання (донавчання). При оцінці якості роботи мережі на ії вхід подаються дані з тестової вибірки, на основі яких вона обчислює вектор відхилень (різниця між виходом нейронної мережі і бажаними характеристиками).

Нейромережева модель авіаційного двигуна TB3-117 є гнучким «інструментом» у процесі ідентифікації параметрів його технічного стану у режимі реального часу. Спектр задач, що вирішуються такою моделлю, досить широкий: від завдань контролю технічного стану двигуна до налагодження його параметрів.

Основні етапи інженерної методики побудови нейромережевої моделі, запропонованої автором, яка буде в подальшому уточнюватися залежно від специфіки розв'язуваної задачі, включає в себе: попередній аналіз даних на етапі постановки задачі й вибору архітектури нейронної мережі, перетворення даних (попередня обробка) для побудови більш ефективної процедури налаштування мережі, вибір архітектури нейронної мережі, вибір структури нейронної мережі, вибір алгоритму навчання, навчання i тестування нейронної мережі, аналіз точності нейромережевого рішення, прийняття рішення на основі отриманих результатів.

Нейронні мережі мають низки незаперечних переваг [2, 11]:

- вони здатні вирішувати погано формалізовані традиційними математичними методами задачі, до числа яких належить ідентифікація двигуна ТВ3-117 як об'єкта спостереження та класифікація його інформаційно-ідентифікаційних ознак за класами функціональних станів;

- розв'язок зазначених задач можливий у режимі реального часу за рахунок високої швидкості роботи нейронної мережі, що особливо важливо для бортової системи;

- зважаючи на різноманіття зв'язків у нейронній мережі, ï надійна робота можлива навіть за пошкодженні деяких з них;

- у процесі своєї роботи нейронна мережа здатна самонавчатися відповідно до змінювальних у процесі експлуатації двигуна параметрів.

Таким чином, застосування нейронних мереж при вирішенні задач ідентифікації технічного стану авіаційного двигуна ТВ3-117, до якої належить задача прогнозування, $є$ сучасним засобом при розро- 
бці бортової системи технічної діагностики авіаційного двигуна ТВ3-117.

\section{Прогнозування технічного стану авіаційного двигуна ТВ3-117}

Відомо, що експлуатація двигуна ТВ3-117 по фактичному технічному стану є найбільш ефективною стратегією його обслуговування. У рамках цієї стратегії актуальним є розв'язок задачі прогнозування технічного стану авіаційного двигуна, що дозволяє отримати інформацію про поведінку його параметрів 3 попередженням, тобто в майбутні моменти часу, і на підставі цього приймати відповідні рішення про зміну режимів його експлуатації.

Нехай є часовий ряд, останні $\mathrm{N}$ відліків якого приймають вид:

$$
\mathrm{Y}(\mathrm{t}-\mathrm{N}+1), \mathrm{Y}(\mathrm{t}-\mathrm{N}+2), \ldots, \mathrm{Y}(\mathrm{t})
$$

де $\mathrm{Y}$ - вектор контрольованих параметрів двигуна; $\mathrm{t}$ - дискретний час.

Задача прогнозування у нейромережевому базисі зводиться до побудови нейромережевої моделі (предиктора), що дозволяє знайти значення вектору $\mathrm{Y}$ в момент часу $\mathrm{t}+1$ за попередніми $\mathrm{N}$ значеннями часового ряду, тобто

$$
\mathrm{Y}(\mathrm{t}+1)=\mathrm{f}[\mathrm{Y}(\mathrm{t}), \mathrm{Y}(\mathrm{t}-1), \ldots, \mathrm{Y}(\mathrm{t}-\mathrm{N}+1)]
$$

де $\mathrm{Y}(\bullet)$ - деяка нелінійна вектор-функція, яку потрібно оцінити за допомогою нейронної мережі.

Точність прогнозу, що реалізується за допомогою нейронної мережі, оцінюється величиною:

$$
\left\|\varepsilon_{t+1}\right\|=\left\|\widehat{Y}_{t+1}-Y_{t+1}\right\|
$$

де $\widehat{Y}_{t+1}$ - прогнозоване значення, обчислене нейронною мережею для моменту часу $\mathrm{t}+1 ; \mathrm{Y}_{\mathrm{t}+1}-$ peальне значення вектору Y в цей же момент часу; $\varepsilon_{t+1}$ - помилка прогнозування.

У даний час відома низка методів прогнозування, таких як: евристичні методи, математичні методи часової екстраполяції, математичні методи просторової екстраполяції, методи моделювання процесів розвитку, логічні і структурні методи $[12,13]$.

Однак, для їх застосування необхідна наявність великих обсягів апріорної інформації про досліджуваний двигун ТВ3-117, значення законів розподілу їх параметрів, математичних моделей, що описують процеси зміни режимів роботи двигуна, в рамках яких можна здійснювати вибір критеріїв і прогнозувальних функцій для розв'язання задачі прогнозу- вання параметрів двигуна ТВ3-117. При індивідуальному прогнозуванні апріорна інформація повинна бути індивідуальною для кожного двигуна.

До недоліків перерахованих вище методів слід віднести [14]: малу робасніть в умовах шумів; нездатність видавати багатопараметричний прогноз 3 урахуванням емерджентності явищ; неможливість оперативної обробки інформації на ЕОМ; складність обробки даних, представлених у різнотипних шкалах тощо.

Розв'язання задачі прогнозування технічного стану двигуна ТВ3-117 у нейромережевому базисі дозволяє використовувати такі переваги нейронних мереж, як: здатність здійснювати багатопараметричний прогноз [13], нечутливість до нестачі апріорної i апостеріорної інформації про динаміку прогнозованих процесів, можливість обробки даних, представлених у різнотипних шкалах, здатність до узагальнення і донавчання, робасніть по відношенню до зовнішніх збурень тощо.

У даній роботі досліджувалися два підходи до розв'язання задачі прогнозування стану двигуна TB3-117, засновані:

а) на використанні рекурентної (динамічної) нейронної мережі, що реалізує залежність виду (2);

б) статичної нейронної мережі, що реалізує часову залежність $\mathrm{Y}=\mathrm{f}(\mathrm{t})$.

Відомо, що для прогнозування технічного стану динамічних об'єктів широко застосовуються рекурентні нейронні мережі, особливості застосування яких для прогнозування технічного стану авіаційних двигунів детально описані у [15], де зроблений порівняльний аналіз точності даного методу з відомими класичними алгоритмами прогнозування і зроблено висновок про можливість застосування нейронних мереж для розв'язання поставленої задачі.

У даній роботі для прогнозування технічного стану двигуна ТВ3-117 застосовано другий підхід, який базується на побудові екстраполюючих функцій $\mathrm{y}(\mathrm{t})$ як функції часу $\mathrm{y}_{\mathrm{i}}(\mathrm{t})=\mathrm{y}(\mathrm{t})$, де $\mathrm{t}-$ поточний час.

Реалізація даного підходу в нейромережевому базисі здійснюється наступним чином:

- виділяється часовий інтервал (інтервал спостереження), який є навчальною вибіркою для нейронної мережі ( $\mathrm{t}$ - вхід нейронної мережі; параметри $\mathrm{y}_{1}, \mathrm{y}_{2}, \ldots, \mathrm{y}_{\mathrm{n}}$ двигуна - ï виходи);

- задається крок прогнозу - $\mathrm{T}_{\text {прогн }} 3$ урахуванням вимог до прогнозу (короткостроковий, середньостроковий, довгостроковий прогноз);

- після процесу навчання нейронної мережі на

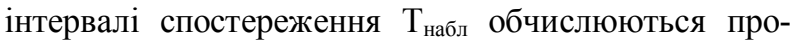
гнозовані значення $\mathrm{yi}_{\mathrm{i}}\left(\mathrm{t}+\mathrm{T}_{\text {прогн}}\right)$. Для цього на вхід нейронної мережі подається значення часу $\mathrm{t}+\mathrm{T}_{\text {прогн. }}$ 
- далі процес прогнозування повторюється в режимі реального часу.

Вихідними даними є виміряні параметри двигуна ТВ3-117 (табл. 1): $\mathrm{T}_{\mathrm{pr}}$ - поточний час процесу експлуатації, приведений до базового значення $\mathrm{T}_{0}=126,5$ год; $\mathrm{N}_{\mathrm{k} \_ \text {ot }}-$ частота обертання ротора компресора, \%; $\mathrm{T}_{3 \_ \text {ot }}$ - температура газу на виході турбіни компресора, приведена до базового значення $\mathrm{T}_{30}=908 \mathrm{~K}$.

Як показали результати порівняльного аналізу, в якості архітектури нейронної мережі найбільш доцільно вибрати багатошарову мережу прямого поширення.

Результати експериментальних досліджень нейронної мережі наведені на рис. 1, звідки випливає, що мінімальна помилка навчання нейронної мережі на інтервалі спостереження, яка містить 12 відліків, забезпечується при числі нейронів прихованого шару, що дорівнює шести.

При оцінюванні ефективності нейромережевого прогнозування технічного стану двигуна ТВ3-117 здійснюється порівняльний аналіз 3 низкою класичних методів: експоненціального згладжування, змінної середньої, методу найменших квадратів, при цьому прогноз за методом змінної середньої здійснювався за формулою:

$$
\mathrm{y}_{\mathrm{t}+1}=\frac{1}{\mathrm{~N}} \sum_{\mathrm{b}=0}^{\mathrm{N}} \mathrm{y}_{\mathrm{t}-\mathrm{b}+1}
$$

де $\mathrm{N}$ - кількість попередніх періодів, що входять до ковзного середнього; $\mathrm{y}_{\mathrm{t}}-$ фактичне значення в мо- мент часу; $\mathrm{y}_{\mathrm{t}+1}-$ прогнозоване значення в момент часу $\mathrm{t}+1$.

Для прогнозу за методом експоненціального згладжування застосовувався вираз:

$$
\mathrm{y}_{\mathrm{t}+1}=\mathrm{y}_{\mathrm{t}}+\alpha\left(\mathrm{A}_{\mathrm{t}}-\mathrm{y}_{\mathrm{t}}\right)+\alpha \mathrm{A}_{\mathrm{t}}+(1-\alpha) \mathrm{y}_{\mathrm{t}}
$$

де $\mathrm{y}_{\mathrm{t}+1}$ - передбачене значення параметра на основі попереднього значення $\mathrm{yt}_{\mathrm{t}}$, скоригованого 3 урахуванням похибки прогнозу $\mathrm{A}_{\mathrm{t}}-\mathrm{y}_{\mathrm{t}}$ i вагового коефіцієнта $\alpha(0<\alpha<1)$.

Експериментальні дослідження розв'язання задачі прогнозу за допомогою методу найменших квадратів показали, що функція $\mathrm{f}(\mathrm{t})$, що екстраполюється, може бути обрана у вигляді полінома дев'ятого порядку.

Подальше зростання ступеня полінома практично не забезпечує зменшення похибки апроксимації функції $\mathrm{Y}=\mathrm{f}(\mathrm{t})$.

На рис. 2 наведено результати порівняльного аналізу нейромережевого і класичних методів прогнозування стану двигуна ТВ3-117 для температури газу за турбіною компресора, як найбільш значимого параметра.

На рис. 2. позначено: 1 - реальне значення температури газу за турбіною; 2 - значення температури газів, обчислене 3 використанням методу експоненціального згладжування; 3 - значення температури газів, обчислене на основі методу змінної середньої; 4 - значення температури газів, обчислене 3 використанням методу найменших квадратів; 5 - значення температури газів, обчислене 3 використанням нейронної мережі.

Таблиця 1

Фрагмент навчальної вибірки за результатами експлуатації двигуна ТВ3-117

\begin{tabular}{|c|l|l|l|l|l|l|l|l|}
\hline $\mathrm{T}_{\mathrm{pr}}$ & 0,843 & 0,872 & 0,882 & 0,897 & 0,892 & 0,904 & 0,903 & 0,906 \\
\hline $\mathrm{N}_{\mathrm{k} \_ \text {ot }}$ & 0,875 & 0,894 & 0,895 & 0,893 & 0,895 & 0,897 & 0,885 & 0,876 \\
\hline $\mathrm{T}_{\text {3_ot }}$ & 0,592 & 0,585 & 0,591 & 0,595 & 0,593 & 0,592 & 0,593 & 0,591 \\
\hline $\mathrm{T}_{\mathrm{pr}}$ & 0,904 & 0,903 & 0,902 & 0,916 & 0,911 & 0,913 & 0,921 & 0,928 \\
\hline $\mathrm{N}_{\mathrm{k} \_ \text {ot }}$ & 0,881 & 0,878 & 0,883 & 0,881 & 0,875 & 0,905 & 0,836 & 0,853 \\
\hline $\mathrm{T}_{\text {3_ot }}$ & 0,603 & 0,591 & 0,605 & 0,609 & 0,592 & 0,601 & 0,593 & 0,585 \\
\hline
\end{tabular}

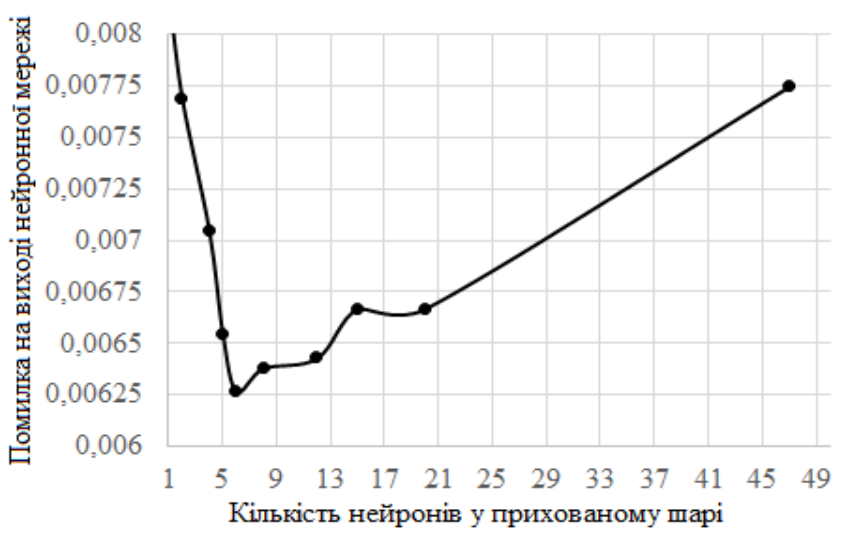

Рис. 1. Графік залежності помилки навчання нейронної мережі від числа нейронів прихованого шару 


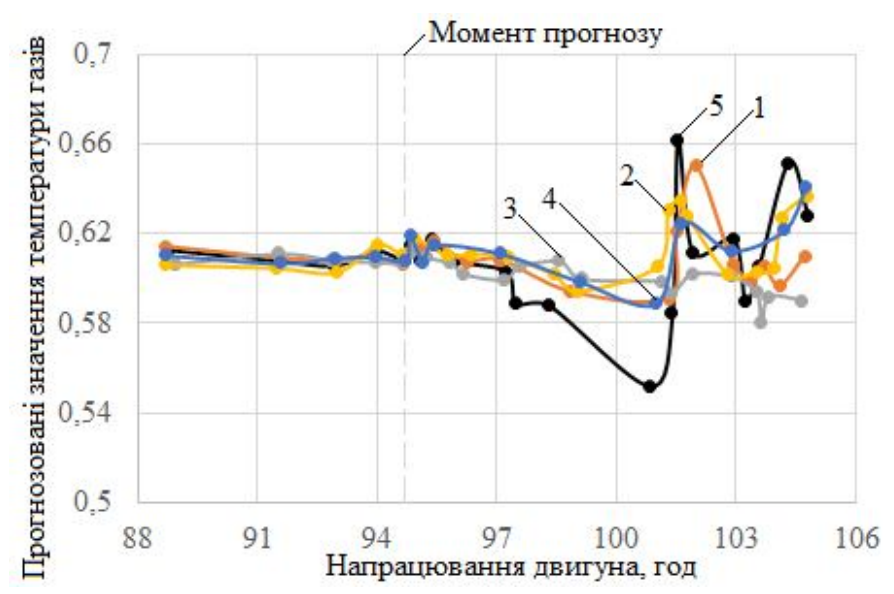

Рис. 2. Результати прогнозу температури газу за турбіною компресора

На рис. 2 інтервал часу $3 \mathrm{t}=88,7$ год по $\mathrm{t}=95,1$ год відповідає інтервалу спостереження і $\epsilon$ навчальною вибіркою (у табл. 1 цьому інтервалу відповідають нормалізовані дані з 0,849 по 0,910).

У процесі виконання завдання прогнозування крок $\Delta \mathrm{t}$ відповідав: в задачі короткострокового прогнозування $\Delta \mathrm{t}=0,4$ год; в задачі середньострокового прогнозування $\Delta \mathrm{t}=2$ год; в задачі довгострокового прогнозування $\Delta \mathrm{t}=4$ год.

На рис. 2 прийнято, що момент прогнозу дорівнює $\mathrm{t}=95,1$ год; інтервал часу $\mathrm{t} \in[95,1 ; 96,3]$ відповідає короткостроковому прогнозуванню, $\mathrm{t} \in[95,1 ; 101,1]$ - середньостроковому прогнозуванню, $\mathrm{t} \in[95,1 ; 103,1]$ - довгостроковому прогнозуванню.

Результати порівняльного аналізу роботи класичних i нейромережевого методів прогнозування технічного стану двигуна ТВ3-117 наведено у табл. 2 і на рис. 3.
У табл. 2 використовуються наступні позначення: К - короткостроковий прогноз; С - середньостроковий прогноз; Д - довгостроковий прогноз; MAM - метод змінної середньої; MES - метод експоненціального згладжування; MLS - метод найменших квадратів; NN - нейронна мережа (персептрон). У табл. 2 наведені результати прогнозу для двох випадків:

а) «чисті» вимірювання, отримані за відсутності додаткових випадкових перешкод (суцільні лінії на рис. 3);

б) вимірювання за наявності адитивної випадкової перешкоди у вигляді білого шуму $(\sigma=0,01$; M=0) (штрих-пунктирні лінії на рис. 3).

На рис. 3 помилка прогнозу $\delta_{\text {іпрогн }}=\max _{\mathrm{i}}\left|\delta_{\text {іпрогн }}\right|$ для температури газу за турбіною компресора $\mathrm{T}_{3}$ відповідає використанню $\mathrm{T}_{3}$ мАм - методу змінної середньої, T3_меs - методу експоненціального згладжування, $\mathrm{T}_{3}$ мLS - методу найменших квадратів, $\mathrm{T}_{3 \_\mathrm{NN}}-$ нейромережевого методу, при цьому

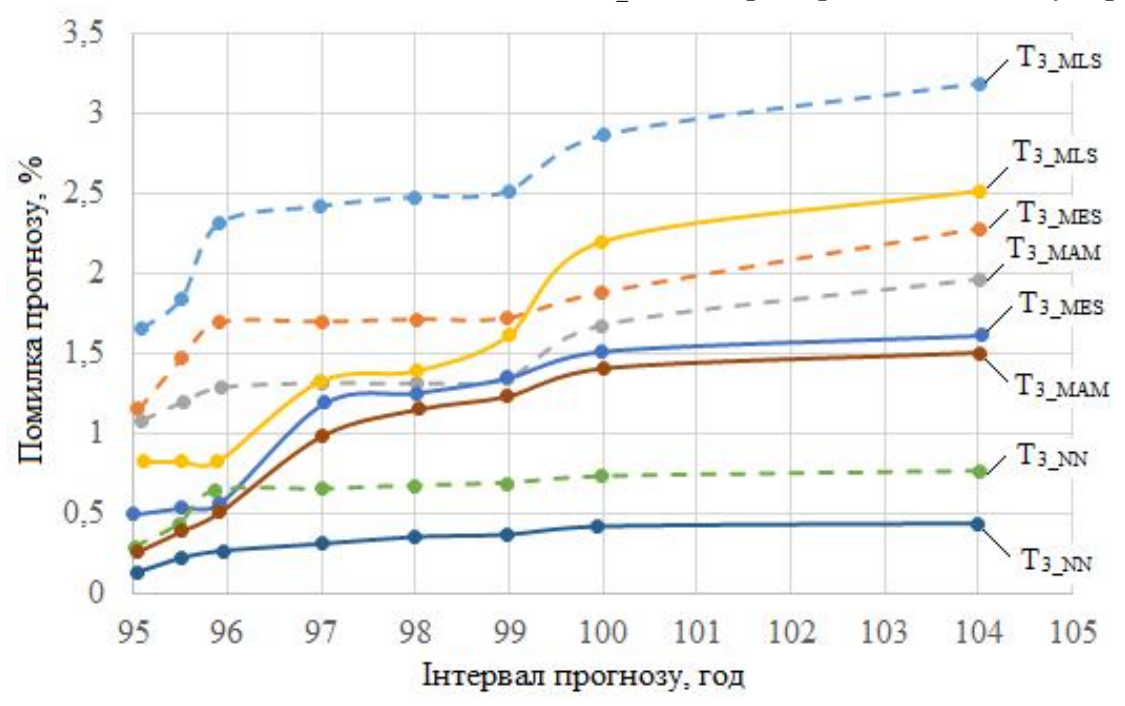

Рис. 3. Залежність зміни помилки прогнозу від інтервалу прогнозу 
Таблиця 2

Результати порівняльного аналізу роботи класичних

і нейромережевого методів прогнозування технічного стану двигуна ТВ3-117

\begin{tabular}{|c|c|c|c|c|c|c|c|c|c|c|}
\hline \multirow{3}{*}{$\begin{array}{c}\text { Методи } \\
\text { прогнозування }\end{array}$} & \multirow{3}{*}{$\begin{array}{c}\text { Назва } \\
\text { методу }\end{array}$} & \multicolumn{9}{|c|}{ Помилка прогнозу параметра двигуна } \\
\hline & & \multicolumn{3}{|c|}{$\mathrm{n}_{1}, \%$} & \multicolumn{3}{|c|}{$\mathrm{n}_{2}, \%$} & \multicolumn{3}{|c|}{$\mathrm{T}_{4}, \%$} \\
\hline & & $\bar{K}$ & $\mathrm{C}$ & Д & $\mathrm{K}$ & $\mathrm{C}$ & Д & K & $\mathrm{C}$ & Д \\
\hline \multirow{3}{*}{$\begin{array}{c}\text { Класичні } \\
\text { (без шуму) }\end{array}$} & MAM & 0,528 & 0,661 & 1,317 & 0,652 & 1,328 & 1,498 & 0,827 & 1,452 & 1,696 \\
\hline & MES & 0,297 & 0,457 & 1,259 & 0,687 & 1,376 & 2,291 & 0,525 & 1,317 & 1,592 \\
\hline & MLS & 0,692 & 0,795 & 1,693 & 0,687 & 1,492 & 1,996 & 0,492 & 1,593 & 2,497 \\
\hline $\begin{array}{l}\text { Нейромережевий } \\
\text { (без шуму) }\end{array}$ & NN & 0,235 & 0,304 & 0,465 & 0,374 & 0,405 & 0,676 & 0,243 & 0,365 & 0,417 \\
\hline \multirow{3}{*}{$\begin{array}{l}\text { Класичні } \\
\text { (3 шумом) }\end{array}$} & MAM & 1,524 & 1,863 & 2,408 & 1,102 & 1,317 & 2,197 & 1,276 & 1,308 & 1,963 \\
\hline & MES & 1,726 & 1,742 & 2,335 & 1,743 & 1,763 & 2,208 & 1,662 & 1,685 & 2,274 \\
\hline & MLS & 2,148 & 2,204 & 2,447 & 2,526 & 2,691 & 3,244 & 2,324 & 2,525 & 3,195 \\
\hline $\begin{array}{c}\text { Нейромережевий } \\
\text { (3 шумом) }\end{array}$ & NN & 0,682 & 0,719 & 0,726 & 0,549 & 0,618 & 0,703 & 0,625 & 0,643 & 0,726 \\
\hline
\end{tabular}

суцільна лінія відповідає помилкам прогнозу за відсутності шуму, а штрих-пунктирна - помилкам прогнозу за наявності адитивної перешкоди (шуму).

Аналіз результатів, наведених у табл. 2 і на рис. 3, свідчить про високу якість прогнозування за допомогою нейромережевого методу.

Так, в умовах відсутності адитивної перешкоди точність короткострокового, середньострокового і довгострокового прогнозу температури газів за допомогою нейронних мереж вища у порівнянні 3 методом найменших квадратів відповідно у 2; 4,32 і 5,95 рази. Аналогічна похибка прогнозування на основі методу змінної середньої для короткострокового, середньострокового i довгострокового прогнозу температури газу вища у порівнянні 3 нейромережевим методом відповідно у 3,3; 3,95 і 4 рази; а для методу експоненціального згладжування на аналогічних ділянках прогнозу температури газу похибка прогнозування також вища у порівнянні 3 нейромережевим методом відповідно у 2,1; 3,57 i 3,81 рази. В умовах наявності перешкоди точність короткострокового, середньострокового і довгострокового прогнозу температури газу з використанням нейромережевого методу у порівнянні 3 методом найменших квадратів також вища відповідно в 3,67; 3,89 і 4,38 рази. Похибка методу змінної середньої в цих умовах на аналогічних інтервалах прогнозу температури газу істотно вища у порівнянні 3 нейромережевим методом відповідно у 2; 2,1 і 2,7 рази; а для методу експоненціального згладжування в цих умовах похибка також вища у порівнянні 3 нейромережевим методом відповідно в 2,65; 2,6 і 3 рази.

Розв'язання розглянутої вище задачі прогнозування температури газу $\mathrm{T}_{3}$ на основі нейронних мереж показано, що в період $3 \mathrm{t}=95,1$ по $\mathrm{t}=104,7$ год помітна стійка тенденція до деградації параметра $\mathrm{T}_{3}$, що свідчить про появу несправності у роботі авіаційного двигуна. Результати прогнозу показують, що, починаючи з $\mathrm{t}=98$ год, необхідно зупинити роботу двигуна і зняти його з експлуатації. Своєчасне прийняття цього рішення дозволить не допустити серйозних руйнувань вузла компресора двигуна, які у даному випадку $\epsilon$ результатом помпірованія лопаток першого ступеня компресора.

\section{Заключення}

У процесі виконання задачі прогнозування технічного стану авіаційного двигуна ТВ3-117 показано, що:

- точність здійснення короткострокового, середньострокового, довгострокового прогнозу за допомогою нейронної мережі значно вища у порівнянні 3 методом найменших квадратів. Інші класичні методи прогнозування (змінного середнього, експоненціального згладжування) також програють по точності по відношенню 3 нейромережевим методом як в умовах відсутності, так і за наявності перешкод;

- застосування розробленого нейромережевого методу прогнозування дозволяє виявляти моменти розладнання часового ряду, тобто поява тренду параметрів двигуна, що є наслідком якісної зміни характеристик двигуна, що дозволяє своєчасно приймати оперативні рішення щодо зміни режиму експлуатації двигуна ТВ3-117.

\section{Литература}

1. Complex Condition Monitoring System of Aircraft Gas Turbine Engine [Text] / A. M. Pashayev, D. D. Askerov, C. Ardil, R. A. Sadiqov, P. S. Abdullayev // International Journal of Aerospace and Mechanical Engineering. - 2007. - Vol. 1, No. 11. - P. 689-695.

2. Легконогих, Д. С. Применение нейросетевых технологий в системах диагностики авиационных силовых установок [Текст] / Д. С. Легконогих // Из- 
вестия Самарского научного иентра Российской академии наук. - 2012. - T. 14, № 4(2). - C. 639-643.

3. Ntantis, E. L. Diagnostic Methods for an Aircraft Engine Performance [Text] / E. L. Ntantis, P. N. Botsaris // Journal of Engineering Science and Technology. - 2015. - Review 8(4). - P. 64-72.

4. Машошин, О. Ф. Диагностика авиационного газотурбинного двигателя по наличию вредных примесей в системе кондиционирования воздуха [Текст] / О. Ф. Машошин, Г. С. Зонтов // Научный вестник МГТУ ГА. - 2014. - № 205. - C. 44-48.

5. Машошин, О. Ф. Оиенка диагностической цеенности информации при решении задач в области эксплуатации авиаџионной техники [Текст] / О. Ф. Машошин // Научный вестник МГТУ ГА. - 2015. - № 219. - C. 53-56.

6. Машошин, О. Ф. Алгоритм оценки вибросостояния газотурбинных двигателей с использованием элементов теории математической статистики [Текст] / О.Ф. Машошин, М. В. Кармызов, В. П. Макаров // Научный вестник МГТУ ГА. - 2008. - № 135. - C. 28-33.

7. Жернаков, С. В. Бортовые алгоритмы контроля параметров ГТД на основе технологии нейронных сетей [Текст] / С. В. Жернаков, В. И. Васильев, И. И. Муслухов // Вестник УГАТУ. 2009. - T. 12, № 1 (30). - C. 61-74.

8. Жернаков С. В. Тренд-анализ параметров авиачионного ГТД на основе технологии нейронных сетей [Текст] / С. В. Жернаков // Вестник УГАТУ. - 2011. - T. 15, № 4 (44). - C. 25-32.

9. Жернаков, С. В. Контроль и диагностика технического состояния масляной системы ГТД с использованием технологии нейронных сетей [Текст] / С. В. Жернаков, Н. С. Иванова, Р. Ф. Равилов // Вестник УГАТУ. - 2012. - Т. 16, № 2 (47). - C. 210-220.

10. Машошин, О. Ф. Диагностика авиаџионной техники [Текст] / О. Ф. Машошин. - М. : МГТУ ГА, 2007. - C. 104-122.

11. Kiakojoori, S. Dynamic neural networks for gas turbine engine degradation prediction, health monitoring and prognosis [Text] / S. Kiakojoori, K. Khorasani // Neural Computing \& Applications. - 2016. - Vol. 27, Issue 8. - P. 2157-2192.

12. Афанасьев, В. Н. Анализ временньх рядов и прогнозирование [Текст] / B. H. Афанасьев, П. Н. Юзбашев. - М. : Финансы и статистика, 2001. $-288 \mathrm{c}$.

13. Назаров, А. В. Нейросетевые алгоритмы прогнозирования и оптимизации систем [Текст] / А. В. Назаров, А. И. Лоскутов. - СПб. : Наука и техника, 2003. - 384 c.

14. Нейронные сети в системах автоматизаичии [Текст] / В. И. Архангельский, И. Н. Богаенко, Г. Г. Грабовский и др. - К. : Техника, 1999. - 364 c.

15. Нейрокомпьютеры в авиации [Текст] : монография / А. И. Галушкин, В. И. Васильев, Б. Г. Ильясов, С. В. Жернаков и др. - М. : Радиотехника, 2004. - 496 с.

\section{References}

1. Pashayev, A. M., Askerov, D. D., Ardil, C., Sadiqov, R. A., Abdullayev, P. S. Complex Condition Monitoring System of Aircraft Gas Turbine Engine. International Journal of Aerospace and Mechanical Engineering, 2007, vol. 1, no. 11, pp. 689-695.

2. Legkonogih, D. S. Primenenie neirosetevih tehnologiy $\mathrm{v}$ sistemah diagnostiki aviatsionnih silovih ustanovok [Application of neural network technologies in aircraft power plant diagnostic systems]. Bulletin of the Samara Scientific Center of the Russian Academy of Sciences, 2012, vol. 14, no. 4(2), pp. 639-643.

3. Ntantis, E. L., Botsaris, P. N. Diagnostic Methods for an Aircraft Engine Performance. Journal of Engineering Science and Technology, 2015, no. 8(4), pp. 64-72.

4. Mashoshin, O. F., Zontov, G. S. Diagnostika aviatsyonnogo gazoturbinnogo dvigatelya po nalichiyu vrednyh primesey $\mathrm{v}$ sisteme konditsionirovaniya vozduha [Diagnosis of an aviation gas turbine engine for the presence of harmful impurities in the air conditioning system]. Scientific Bulletin of the Moscow State Technical University of Civil Aviation, 2014, no. 205, pp. 44-48.

5. Mashoshin, O. F. Otsenka diagnosticheskoy tsennosti informatsiy pri reshenii zadach $\mathrm{v}$ oblasti ekspluatatsiy aviatsionnoy tehniki [Assessment of the diagnostic value of information in solving problems in the field of the operation of aircraft]. Scientific Bulletin of the Moscow State Technical University of Civil Aviation, 2015, no. 219, pp. 53-56.

6. Mashoshin, O. F., Karmyzov, M. V., Makarov V. P. Algoritm otsenki vibrosostoyaniya gazoturbinnih dvigatelei $\mathrm{s}$ ispolzovaniem elementov teoriy matematicheskoi statistiki [Algorithm for estimating the vibration state of gas turbine engines using elements of the theory of mathematical statistics]. Scientific Bulletin of the Moscow State Technical University of Civil Aviation, 2008, no. 135, pp. 28-33.

7. Gernakov, S. V., Vasiliev,V. I., Musluhov I. I. Bortovie algoritmi kontrolya parametrov GTD na osnove tehnologii neironnih setei [On-board algorithms for monitoring GTE parameters based on neural network technology]. Bulletin of the USATU, 2009, vol. 12, no. 1 (30), pp. 61-74.

8. Gernakov, S. V. Trend-analiz parametrov aviatsionnogo GTD na osnove tehnologii neironnih setei [Trend analysis of aviation GTE parameters based on neural network technology]. Bulletin of the USATU, 2011, vol. 15, no. 4 (44), pp. 25-32.

9. Gernakov, S. V., Ivanova, N. S., Ravilov, R. F. Kontrol i diagnostika tehnicheskogo sostoyaniya maslyanoi sistemi GTD s ispolzovaniem tehnologii neironnih setei [Control and diagnostics of the technical state of the GTE oil system using the technology of neural networks]. Bulletin of the USATU, 2012, vol. 16, no. 2 (47), pp. 210-220.

10. Mashoshin, O. F. Diagnostika aviatsionnoy tehniki [Diagnostics of aircraft], Moscow, Moscow 
State Technical University of Civil Aviation Publ., 2007, pp. 104-122.

11. Kiakojoori, S., Khorasani, K. Dynamic neural networks for gas turbine engine degradation prediction, health monitoring and prognosis. Neural Computing \& Applications, 2016, vol. 27, no. 8, pp. 2157-2192.

12. Afanasiev, V. N., Yuzbashev, P. N. Analiz vremennih ryadov i prognozirovanie [Time series analysis and forecasting]. Moscow, Finance and Statistics Publ., 2001. 288 p.

13. Nazarov, A. V., Loskutov, A. I. Neirosetevie algoritmy prognozirovaniya $i$ optimizatsyi sistem $[\mathrm{Neu}-$ ral network algorithms for forecasting and optimization of systems]. St. Petersburg, Science and technology Publ., 2003. 384 p.

14. Arhangelskiy, V. I., Bogaenko, I. N., Graboskiy, G. G. and etc. Neironnie seti v sistemah avtomatizatsyi [Neural networks in automation systems], Kiev, Technique Publ., 1999. 364 p.

15. Galushkin, A. I., Vasilev, V. I., Illyasov, B. G., Gernakov, S. V. and etc. Neirokomputeri $v$ aviatsyi: monografia [Neurocomputers in aviation: monograph]. Moscow, Radio engineering Publ., 2004. 496 p.

\section{ПРИМЕНЕНИЕ НЕЙРОННЫХ СЕТЕЙ В ЗАДАЧИ ПРОГНОЗИРОВАНИЯ ТЕХНИЧЕСКОГО СОСТОЯНИЯ АВИАЦИОННОГО ДВИГАТЕЛЯ ТВЗ-117 В ПОЛЕТНЫХ РЕЖИМАХ}

\section{Ю. Н. Шмелев, С. И. Владов, Я. Р. Климова}

Предметом изучения в статье являются методы и модели идентификации технического состояния авиационного двигателя ТВ3-117. Целью является разработка бортовой системы идентификации технического состояния авиационного двигателя ТВ3-117, одной из решаемых задач которой является прогнозирование его технического состояния в режиме реального времени. Задачи: разработка методов и алгоритмов прогнозирования технического состояния авиационного двигателя ТВ3-117 в полетных режимах на базе нейросетевой технологии. Используемыми методами являются: методы теории вероятностей и математической статистики, методы нейроинформатики, методы теории информационных систем и обработки данных. Получены следующие результаты. Применение предложенного в работе нейросетевого метода прогнозирования, основанного на аппроксимации и экстраполяции процессов изменения газодинамических параметров авиационного двигателя ТВ3-117 на фиксированных отрезках временного окна (в пределах «скользящего временного окна»), позволяет эффективно решать задачи прогнозирования его технического состояния. Анализ эффективности применения нейросетевого метода прогнозирования технического состояния авиационного двигателя ТВ3-117 в условиях действия случайных помех показывает его преимущества по сравнению с классическими методами прогнозирования, заключающиеся в обеспечении более высокой точности прогнозирования для различных интервалов прогноза (краткосрочное, среднесрочное, долгосрочное прогнозирование). Применение разработанного нейросетевого метода позволяет обнаруживать моменты разладки временного ряда, то есть появление тренда параметров авиационного двигателя ТВ3-117, являющегося следствием качественного изменения характеристик двигателя, что позволяет своевременно принимать оперативные решения по изменению режима его эксплуатации. Выводы. Научная новизна полученных результатов состоит в следующем: получил дальнейшее развитие метод решения задачи прогнозирования технического состояния авиационного двигателя ТВ3-117 с помощью нейросетевых технологий, точность которого при краткосрочном среднесрочном и долгосрочном прогнозе значительно выше по сравнению с использованием полиномиальных регрессионных моделей, метода экспоненциального сглаживания, скользящего среднего, что свидетельствует о том, что использование нейросетевых технологий позволяет обнаруживать появление тренда параметров авиационного двигателя ТВ3-117, что позволяет принимать своевременные оперативные решения по изменению режима его эксплуатации.

Ключевые слова: авиационный двигатель, нейронная сеть, прогнозирование, временной ряд, ошибка.

\section{APPLICATION OF NEURAL NETWORKS IN PROBLEM OF PREDICTING THE TECHNICAL CONDITION OF AVIATION ENGINE TV3-117 IN FLIGHT MODES}

\section{Y. M. Shmelov, S. I. Vladov, Y. R. Klimova}

The subject matter of the article are the methods and models for the identification of the technical state of the aircraft engine TV3-117. The goal is to develop an on-board system for identification of the technical state of the aircraft engine TV3-117, one of the solved tasks is the prediction of its technical status in real time. The tasks to be solved are: to development of methods and algorithms for forecasting the technical state of the aircraft engine TV3117 in flight modes based on neural network technology. The methods used are: methods of probability theory and mathematical statistics, methods of neuroinformatics, methods of information systems theory and data processing. 
The following results were obtained: the application of the proposed neural network prediction method based on the approximation and extrapolation of the processes of changing the gas dynamic parameters of the aircraft engine TV3-117 on fixed segments of the time window (within the «sliding time window») allows effectively solving the problems of forecasting its technical state. The analysis of the effectiveness of the application of the neural network method for forecasting the technical state of the aircraft engine TV3-117 under the conditions of random interference has shown its advantages in comparison with the classical prediction methods, which consist in providing higher prediction accuracy for different forecasting intervals (short-, medium-, long-term forecasting). Application of the developed neural network method makes it possible to detect the moments of the time series disorder, that is, the appearance of the trend of the parameters of the aircraft engine TV3-117, which is a consequence of the qualitative change in the characteristics of the engine, which allows timely making operative decisions on changing its operation mode. Conclusions. The scientific novelty of the results obtained is as follows: the method of solving the problem of forecasting the technical state of the aircraft engine TV3-117 with the help of neural network technologies has been further developed, the accuracy of which in the short-term medium and longterm forecast is significantly higher compared with the use of polynomial regression models, the method of exponential smoothing, moving average, which indicates that the use of neural network technologies makes it possible to detect the appearance of the trend of the parameters of the aircraft engine TV3-117, which allows is to make timely operational decisions to change its mode of operation.

Keywords: aircraft engine, neural network, forecasting, time series, error.

Шмелев Юрий Николаевич - канд. техн. наук, заместитель начальника колледжа по учебной работе, преподаватель кафедры энергообеспечения и систем управления, Кременчугский летный колледж Национального авиационного университета, Кременчуг, Украина, e-mail: ref.nv.klknau@gmail.com.

Владов Сергей Игоревич - канд. техн. наук, заведующий учебно-методической лаборатории, преподаватель кафедры энергообеспечения и систем управления, Кременчугский лётный колледж Национального авиационного университета, Кременчуг, Украина, e-mail: ser26101968@gmail.com.

Климова Яна Руслановна - преподаватель цикловой комиссии конструкции и эксплуатации воздушных суден и авиадвигателей, Кременчугский летный колледж Национального авиационного университета, Кременчуг, Украина, e-mail: keps.nv.klknau@gmail.com.

Shmelov Yurii Mykolayovich -PhD, Deputy college chief for curriculum, Teacher of department of energy supply and control systems, Kremenchug Flight College of National Aviation University, Kremenchug, Ukraine, e-mail: ref.nv.klknau@gmail.com.

Vladov Serhii Igorovych - PhD, Head of methodical-study laboratory, Teacher of department of energy supply and control systems, Kremenchug Flight College of National Aviation University, Kremenchug, Ukraine, e-mail: ser26101968@gmail.com.

Klimova Yana Ruslanivna - Teacher of department of design and operation of aircraft and aircraft engines, Kremenchug Flight College of National Aviation University, Kremenchug, Ukraine, e-mail: keps.nv.klknau@gmail.com. 